Article

\title{
Sustainable Agri-Food Supply Chain Performance Measurement Model for GMO and Non-GMO Using Data Envelopment Analysis Method
}

\author{
Virda Hersy Lutviana Saputri ${ }^{1, *}$, Wahyudi Sutopo ${ }^{2}$, Muhammad Hisjam ${ }^{2}$ and \\ Azanizawati Ma'aram ${ }^{3}$ (D) \\ 1 Master Program of Industrial Engineering, Universitas Sebelas Maret, Surakarta 57126, Indonesia \\ 2 Department of Industrial Engineering, Faculty of Engineering, Universitas Sebelas Maret, \\ Surakarta 57126, Indonesia; wahyudisutopo@staff.uns.ac.id (W.S.); hisjam@staff.uns.ac.id (M.H.) \\ 3 School of Mechanical Engineering, Faculty of Engineering, Universiti Teknologi Malaysia, \\ 81310 UTM Johor Bahru, Malaysia; niza@utm.my \\ * Correspondence: virdahersy@student.uns.ac.id
}

Received: 30 January 2019; Accepted: 17 March 2019; Published: 21 March 2019

\begin{abstract}
The increase in food demand in Indonesia is one of the consequences of the imbalance between population growth and declining food products. One of alternative technologies that can be used in plant breeding programs to increase agricultural production, in order to meet food demands, is genetically modified organism (GMO) technology. This technology presents a lot of pros and cons among the public-related impacts that will be accepted by consumers. The purpose of this study was to determine the level of sustainability between GMO and non-GMO foods. The performance measurement model for GMO and non-GMO foods was considered according to the seven issues of sustainability that represented environmental, social, and economic aspects. The assessment method was conducted by using Adjusted Profit (AP) with Total Price Recovery (TPR) indicators and Total Factor Productivity (TFP) by utilizing the Data Envelopment Analysis (DEA) Method. Assessments made on each supply chain component included agriculture, processing, and transport to wholesalers/retailers. This study used numerical examples of rice production in Indonesia. The research results found that the performance of non-GMO rice chain is better than GMO rice. It indicates that non-GMO rice is more sustainable. The results show that the proposed model can be applied to measure the sustainability of GMO and Non-GMO agri-food supply chain performance.
\end{abstract}

Keywords: adjusted profit; agri-food supply chain management; DEA; genetically modified organism; performance measurement; sustainability

\section{Introduction}

The supply chain has become a frequently discussed issue in human life, one of which is the agri-food supply chain. Lambert et al. [1] defined the supply chain as a process that adds value to customers and stakeholders through the integration of end-user business processes through genuine suppliers that provide products, services, and information. An agri-food supply chain consists of a set of activities in a "farm-to-fork" sequence including farming, processing/production, testing, packaging, warehousing, transportation, distribution, and marketing [2]. The distinction between the food supply chain and other supply chains is that the former affects a continuous and significant change in the quality of food products, consistently and significantly throughout the supply chain until the end point of the product is consumed by consumers. Hence, the food supply chain lays more emphasis on how companies meet consumer demands not only in providing goods but also in the capability to ensure the availability of raw materials on time by the supplier, to meet consumer 
demands on time, and to maintain the right quantity and quality so that the overall supply chain is improved.

The agri-food industry is a social issue. The agri-food supply chain plays an important role to maintaining the balance of food demand and world population growth [3]. The world population is expected to increase to 8.3 billion by 2030 and to exceed 9.2 billion by 2050 [4]. Along with the increasing world population, food production is also expected to be increase from $70 \%$ to $100 \%$ by 2050 to meet the increasing demand for food [5].

In order to sustain human life, food is one of the most necessary and important elements. Changes in culture and way of life make food availability an important issue for humans. Various efforts have been made to address these challenges, including by applying biotechnology through genetic engineering. With climate change and the rising world population, the expected demand for food can be met by increasing access to genetic resources. One of the important issues is the effect of the widespread application of agricultural biotechnology on biodiversity. An organism resulting from this technique is known as a Genetically Modified Organism (GMO). GMO is a technology used to alter a cell's genetic material to produce new substances or perform new functions [6]. Modifications to an organism provide the capacity for the development of crops to make them compatible with various ecologies. Therefore, technological advances help to increase the diversity of nature and expand the adaptive capabilities [7]. This genetic engineering technology has been shown to produce transgenic crops whose planting area has increased more than 40 times, i.e., from 1.7 ha at the time of introduction in 1996 to 67.7 million ha in 2003 [8].

Apart from the benefits of GMO foods, it is also feared that transgenic foods could cause unknown losses. These losses could have an environmental, social, and economic impact. The environmental issue of GMOs has led to superweeds and superpests that are extraordinarily difficult for farmers to manage. The negative impacts of genetically engineered crops on the environment are very destructive with the loss of biodiversity. This can occur through gene pollution [9]. Additionally, from an economic aspect, competition in trading and marketing of GMO agricultural products will cause injustice to developing agrarian countries due to the far-reaching technological gap with developed countries. The gap arises because modern biotechnology is excessively expensive, which makes it difficult for developing countries to adopt and develop it. Patents owned by producers of transgenic products are also trying to increase the dominance of developed countries. Farmers who plant unlicensed transgenic seeds could get prosecuted for violating property rights. Furthermore, since the commercial introduction of GMOs, the seed industry has rapidly consolidated. Only a few companies control the seed market [10]. Food with genetically modified components may not be labeled. New traits could cause adverse health reactions.

Indonesia imported more than $\$ 1.42$ billion of GMO products in 2014, including Bt corn, herbicide tolerant soybeans and meal, Bt cotton, and various food products derived from GMO crops [11]. GMO products that enter the Indonesian market must enter through a process of inspection by the relevant ministries associated with food safety, feed safety, and environmental safety based on scientific approaches as well as considering esthetic norms, socio-cultural concerns, ethical concerns, and religion. The national competent authorities in Indonesia are the Ministry of Environment and Forestry, the Ministry of Agriculture, the Ministry of Trade, the Ministry of Health, the Ministry of Marine Affairs and Fisheries, and the National Agency of Drug and Food Control (BPOM).

In addition, stakeholders both private and governmental in Indonesia have a special laboratory used to test GMO products. With those labs, Indonesia continues to develop GMO crops, such as: Tomato (resistant to virus), cassava (amylase modification), sugarcane (modification of high glucose levels), rice (efficient use of nitrogen), and delayed ripening papaya. With so many GMO products coming into Indonesia and accompanied by numerous GMO product-testing labs, it is possible for Indonesia to minimize the presence of dangerous GMO products. However, the impacts of GMO products are not yet known. Therefore, the Indonesian must be careful in buying food. 
Along with the growing application of genetically engineered plants, many people have welcomed with positivity and support the application of this technology as a promising food commodity, but there are not a few who oppose it. Most people are concerned with health insurance and its effects on environmental balance, so the use of this technology is still a polemic over whether it can be used as a solution to overcome hunger or whether it will create pollution that brings damage and disaster.

Indonesia has specific needs in raising the capacity of the country to apply transparent and science-based regulations to plant biotechnology, such as: knowledge improvement of technical teams through biosafety training on stacked events of GMO products, finalizing the guidelines for research and development of transgenic products in the laboratory, biosafety containment, and confined fields, as well as developing food safety and feed safety assessment guidelines for stacked events, and monitoring programs. Therefore, this study surely could benefit society, the economy and the nation of Indonesia.

With the number of GMO products that have been developed in Indonesia as well as with the availability of laboratory tests for GMO products, the studies that relate to performance measurements between GMO and non-GMO products are still lacking. Thus, this research is intended to investigate the sustainable supply chain performance of GMO foods compared to non-GMO foods by using the indicator-based approach in data envelopment analysis (DEA). The DEA method was chosen because DEA can measure many inputs and outputs, as well as evaluate quantitative and qualitative measures, making it possible to reasonably assess the efficiency of the units analyzed.

There are several studies about DEA. Sun et al. [12] studied the efficiency evaluation of the operation analysis system from big data using DEA models. Fu et al. [13] studied how to increase the scale of cassava planting and promote cassava production efficiency in China using output-oriented DEA modeling. Ma et al. [14] have applied a super-efficiency data envelopment analysis model with a slack-based measure (Super-SBM DEA) considering undesirable outputs to measure the integrated transport efficiency (ITE) of 31 provinces in China. Then this research was intended to evaluate the efficiency of GMO and non-GMO products; the results of this research are expected to produce a set of performance-measuring frameworks for GMO and non-GMO foods in terms of sustainability using the DEA method.

\section{Materials and Methods}

The data used in this study were primary and secondary data. Primary data were taken from questionnaires and interviews of GMO and non-GMO companies and rice farmers in Java, Indonesia. Secondary data were taken from online resources. Judgment sampling techniques were used to collect the GMO companies' information in Indonesia. Then, we took one product as a case study to be observed by using the seven issues of sustainability developed by Gaitan-Cremaschi et al. [15,16]. In this research, seven issues of sustainability were determined. Biodiversity, atmosphere, materials, and water were selected as issues of the environmental sustainability dimension. Economic performance was selected as an issue of the economic dimension. Then, employment practices and product responsibilities were selected for the social dimension.

Data Envelopment Analysis (DEA) is a non-parametric efficiency evaluation method that uses a mathematical planning model to calculate the distance between each Decision Making Unit (DMU) and the production frontier consisting of the best performing DMUs in practice, and further to calculate the efficiency score of each DMU. The term DMU in DEA can represent a variety of units, such as units from factories, departments, and anything that has similar operational characteristics. There are two factors that influence the selection of DMUs, namely: First, the DMUs must be homogeneous units. These units carry out the same tasks, and have the same objective. Second, the inputs and outputs that characterize the performance of the DMUs must be identical, except that they differ only in their magnitude and size.

Next, in this study the DEA method was used to measure the Total Factor Productivity (TFP) indicator and the Total Price Recovery (TPR). This research used the Adjusted Profit (AP) integrated 
indicator for product comparison in conditions of sustainability. The adjusted profit (AP) indicator provides some input-output properties of the agri-food supply chain, contributes to negative production externalities, and provides one unified sustainability performance measure. This research also used the Total Factor Productivity (TFP) indicator and the Total Price Recovery (TPR) indicator to identify the consistent comparison between the adjusted profits from the different products. With that indicator, the variation in total adjusted profits among the production chains could be divided into variations caused by the difference in price (price represents the difference in TPR) and variations caused by the difference in quantity (quantity represents the difference in TFP) for each input, output, and externality [17-19].

The agri-food supply chain or Decision Making Unit (DMU) for both GMOs and non-GMOs is explained as a set of three stages: $\mathrm{z}=1, \mathrm{z}=2$, and $\mathrm{z}=3$, they are agricultural/farming $(\mathrm{z}=1)$, processing $(z=2)$, and transport to wholesalers/retailers $(z=3)$. At every stage, vector $x$ indicates inputs, such as services, materials, energy, labor, and capital that are turned into outputs (products), symbolized by vector $y$. Some environmental and social externalities are generated as a side effect of production, stated by vector $b$, such as loss of biodiversity, poor working conditions, pollution, and waste. The schematic diagram of an agri-food supply chain in this research is shown in Figure 1.

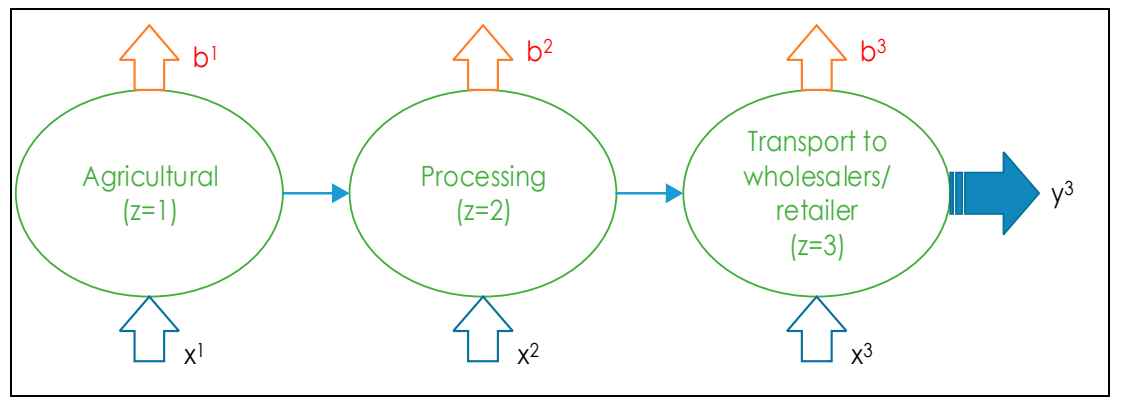

Figure 1. Schematic diagram of an agri-food supply chain.

The value of AP in agri-food supply chains is positive if the difference between the aggregated outputs and the aggregated inputs shows positive results and, vice versa, when the difference between the aggregated outputs and the aggregated inputs is negative then the agri-food supply chain has a negative adjusted profit (AP) as the externalities are output penalties that decrease the score. The score of the AP value is calculated by Equation (1) below:

$$
A P=p^{\prime} y-r^{\prime} b-w / x
$$

Some outputs, inputs, and externalities are aggregated using price vectors $p, w$, and $r$.

It is assumed that there are $\mathrm{k}=1, \ldots, \mathrm{k}$ investigations for the non-GMO food chain and $\mathrm{m}=1$, $\ldots, \mathrm{m}$ investigation for the GMO food chain. The TFP indicator and the TPR indicators are used to evaluate the relative sustainability performance, i.e., to compare the AP within and between the two agri-food supply chains which can be obtained from Equation (2) below:

$$
\begin{aligned}
B_{1,2} & =\left[\frac{1}{2}\left(p_{2}^{\prime}+p_{1}^{\prime}\right)\left(y_{2}-y_{1}\right)\right]-\left[\frac{1}{2}\left(w^{\prime}{ }_{2}+w_{1}^{\prime}{ }_{1}\right)\left(x_{2}-x_{1}\right)\right]-\left[\frac{1}{2}\left(r^{\prime}{ }_{2}+r_{1}^{\prime}\right)\left(b_{2}-b_{1}\right)\right] \\
& +\left[\frac{1}{2}\left(y_{2}+y_{1}\right)\left(p_{2}^{\prime}{ }_{2}-p_{1}^{\prime}{ }_{1}\right)\right]-\left[\frac{1}{2}\left(x_{2}+x_{1}\right)\left(w^{\prime}{ }_{2}-w^{\prime}{ }_{1}\right)\right]-\left[\frac{1}{2}\left(b_{2}+b_{1}\right)\left(r^{\prime}{ }_{2}-r^{\prime}{ }_{1}\right)\right]
\end{aligned}
$$

The best player in the data (in terms of the highest AP) is expressed as 1 and any other investigations, i.e., $k$ or $m$, are expressed as 2. A lower number indicates a low sustainability performance of the observation assessed relative to benchmarks. Differences in adjusted profits between benchmarks and other observations can be divided into two sections. The first section produces the difference in prices $p, w$, and $r$ (TPR part - equation after the sign (+) of Equation (2)) and the second section reflects the difference in the sum of $y, x$, and $b$ (TFP part - equation before the sign 
(+) of Equation (2)). The differences in the AP related with the TFP or TPR part are evaluated at each stage of the agri-food supply chain.

Some of the indicators used in this study were: profitability for the issues materials and economic performance, global warming potential (GWP) for atmosphere, eutrophication potential (EP) for the water issue, deforestation (DEF) and environmental toxicity (ET) as proxies of biodiversity, and farmer toxicity (FT), consumer toxicity (CT), and loss of employment (LE) for product responsibility.

\section{Results and Discussion}

To implement the scheme in Indonesia, the first step is to find out the GMO and non-GMO food products produced in Indonesia. Based on the report from the USDA Foreign Agricultural Service [11], GMO products in Indonesia can be known as shown in Table 1. A lot of GMO rice is developed in Indonesia, thus this research was carried out by analyzing the performance measurement of rice.

Table 1. GMO crops in Indonesia.

\begin{tabular}{ccc}
\hline Crops & Trait & Developer \\
\hline Rice & Nitrogen use efficiency & ICABIOGRAD, Bogor \\
Rice & Drought tolerant & ICABIOGRAD, Bogor \\
Rice & Productivity & ICABIOGRAD, Bogor \\
Rice & Salt tolerant & ICABIOGRAD, Bogor \\
Rice & Brown planthopper resistant & Padjadjaran University, Bandung \\
Sugarcane & High glucose content & PTPN-XI/Jember University, Jember \\
Tomato & Viruses resistance & ICABIOGRAD/RIV, Bogor \\
Tomato & Low seed content & ICABIOGRAD, Bogor \\
Cassava & Low amylose content & ICABIOGRAD/IIS, Bogor \\
Papaya & Delayed ripening & ICABIOGRAD, Bogor \\
Potato & Resistance to Pytophthora & ICABIOGRAD, Bogor \\
Tomato & infestans & Miraculin \\
Rice variety Rojolele & Yellow stem borer resistant & The Indonesian Institute of Science, Jakarta \\
Rice & Drought tolerance & The Indonesian Institute of Science, Jakarta \\
Sugarcane & Availability of P & Bogor Agricultural University, Bogor \\
Rice & Aluminum tolerant & Bogor Agricultural University, Bogor \\
Sugarcane & Drought tolerance & Indonesian Research Institute for \\
& & Biotechnology and Bioindustry, Bogor \\
\hline
\end{tabular}

Source: USDA Foreign Agricultural Service [11].

Indonesia is the world's third largest rice producer after China and India. According to data from the Central Bureau of Statistics [20], Indonesia's rice production was 75.3 million tons in 2015. The rice production comes from 14.11 million hectares of harvested land with productivity of 53.41 quintal of rice/hectare. On the other hand, the population of Indonesia is the largest consumer of rice in the world with a consumption rate of $114 \mathrm{~kg} /$ capita/year. The high production and consumption of rice in Indonesia shows that rice commodities not only concern the interests of producers, but also the needs of consumers. A scarcity of rice will lead to a food crisis. A rice crisis would trigger a crisis chain, triggering other crises such as a nutritional crisis, a health crisis, an economic crisis, a social crisis, and a political crisis. This study utilized two treatment schemes to meet the needs of rice in Indonesia: Consuming GMO and consuming non-GMO rice seeds.

The rice supply chain in Indonesia consists of several subsystems, including supply, production, and consumption. Each subsystem consists of more specific elements. Indonesia's rice supply chain system is cross-sectoral because it includes various related institutions, such as rice consumption subsystems related to population and income issues, while supply subsystems are related to land and agricultural cultivation issues. To analyze the supply chain, the rice supply system was divided into three subsystems, namely supplier subsystem (agricultural as stage 1), producer subsystem (processing as stage 2), and distribution subsystem to wholesalers/retailers (as stage 3 ). In each subsystem there 
are inputs, outputs, and externalities. To facilitate the depiction of a performance measurement system between GMO and non-GMO rice, the following numerical example results from interviews with related parties were used.

We quantified the outputs, inputs, and externalities for GMO and non-GMO rice chains as shown in Tables 2-10.

Table 2. Numerical examples of quantities of output (y), input (x), and prices ( $\mathrm{p}$ and $\mathrm{w}$ ) of GMO and non-GMO rice production in Indonesia.

\begin{tabular}{|c|c|c|c|}
\hline & \multicolumn{3}{|c|}{ Quantity } \\
\hline & Unit & GMO & Non-GMO \\
\hline $\begin{array}{l}\text { Output quantities (y) } \\
\text { Input quantities (x) }\end{array}$ & ton & 1 & 1 \\
\hline \multicolumn{4}{|l|}{ Stage 1} \\
\hline Seed & $\mathrm{kg}$ & 16 & 17.7 \\
\hline Fertilizer & $\mathrm{kg}$ & 68.2 & 68.4 \\
\hline Pesticide & $\mathrm{kg}$ & 2.1 & 1.5 \\
\hline Machinery & hour & 0.8 & 0.8 \\
\hline Labor & hour & 1.2 & 1.1 \\
\hline $\begin{array}{l}\text { Transport } \\
\text { Stage 2 }\end{array}$ & $\mathrm{kg}$ & 32 & 32 \\
\hline $\begin{array}{l}\text { Machinery } \\
\text { Stage } 3\end{array}$ & hour & 1 & 1 \\
\hline \multirow{3}{*}{ Fuel for Transport } & $\mathrm{kg}$ & 145 & 145 \\
\hline & \multicolumn{3}{|c|}{ Price } \\
\hline & Unit & GMO & Non-GMO \\
\hline $\begin{array}{l}\text { Output price }(\mathrm{p}) \\
\text { Input price }(\mathrm{w}) \\
\text { Stage } 1\end{array}$ & $\$ /$ ton & 534.36 & 571.7652 \\
\hline$\overline{\text { Seed }}$ & $\$ / \mathrm{kg}$ & 2.19 & 1.46 \\
\hline Fertilizer & $\$ / \mathrm{kg}$ & 0.37 & 0.37 \\
\hline Pesticide & $\$ / \mathrm{kg}$ & 25.62 & 25.62 \\
\hline Machinery & $\$ /$ hour & 19.2 & 19.2 \\
\hline Labor & $\$ /$ hour & 3.4 & 3.4 \\
\hline $\begin{array}{l}\text { Transport } \\
\text { Stage } 2\end{array}$ & $\$ / \mathrm{kg}$ & 0.2 & 0.2 \\
\hline $\begin{array}{l}\text { Machinery } \\
\text { Stage } 3\end{array}$ & $\$ /$ hour & 0.07 & 0.07 \\
\hline Fuel for Transport & $\$ / \mathrm{kg}$ & 0.2 & 0.2 \\
\hline
\end{tabular}

Table 3. Bad outputs of externalities in rice production.

\begin{tabular}{cccc}
\hline Indicator & \multirow{2}{*}{ Unit } & \multicolumn{2}{c}{ Externalities } \\
\cline { 3 - 4 } Bad Output Quantities (b) & & GMO & Non-GMO \\
\hline GWP & kg CO -eq & & \\
Stage 1 & & 242.7 & 246.7 \\
Stage 2 & & 520.4 & 20.4 \\
Stage 3 & kg P & 0.2 & 668.1 \\
EP & EIQ & 35.8 & 0.4 \\
ET & EIQ & 9.7 & 9.8 \\
FT & EIQ & 5.4 & 4.8 \\
CT & m & 1.5 & 6.5 \\
DEF & hours & 3.0 & 2.4 \\
LE & & & \\
\hline
\end{tabular}


Table 4. Shadow prices of externalities in rice production.

\begin{tabular}{ccc}
\hline Externality & Unit & Shadow price US \$ \\
\hline GWP & $\mathrm{kg} \mathrm{CO}_{2}$-eq & 0.02 \\
EP & $\mathrm{kg} \mathrm{PO}_{4}$-eq & 1.98 \\
DEF & $\mathrm{m}^{2}$ & 0.10 \\
ET & EIQe & 0.02 \\
FT & EIQf & 0.42 \\
CT & EIQc & 0.31 \\
LE & Hour & 3.40 \\
\hline
\end{tabular}

Table 5. Adjusted profit for GMO and non-GMO rice systems.

\begin{tabular}{ccccc}
\hline System & $\mathbf{p}^{\prime} \mathbf{y}$ & $\mathbf{w}^{\prime} \mathbf{x}$ & $\mathbf{r}^{\prime} \mathbf{b}$ & Adjusted Profit (AP) \\
\hline GMO & 534.36 & 168.99 & 32.77 & 332.60 \\
Non-GMO & 571.77 & 144.15 & 33.96 & 393.66 \\
\hline
\end{tabular}

Table 6. Differences in the adjusted profit for GMO and non-GMO systems.

\begin{tabular}{|c|c|c|c|c|c|c|c|}
\hline \multirow{2}{*}{ System } & \multicolumn{2}{|c|}{ Stage 1} & \multicolumn{2}{|c|}{ Stage 2} & \multicolumn{2}{|c|}{ Stage 3} & \multirow{2}{*}{$\begin{array}{c}\text { Adjusted Profit } \\
\text { Differences }\end{array}$} \\
\hline & TFP & TPR & TFP & TPR & TFP & TPR & \\
\hline GMO & 16.36 & -88.26 & 0.00 & 0.00 & 2.96 & -37.41 & -106.34 \\
\hline Non-GMO & 0.00 & 0.00 & 0.00 & 0.00 & 0.00 & 0.00 & 0.00 \\
\hline
\end{tabular}

Table 7. Adjusted profit for GMO and non-GMO rice systems if the quantity for GMOs is raised $10 \%$.

\begin{tabular}{ccccc}
\hline System & $\mathbf{p}^{\prime} \mathbf{y}$ & $\mathbf{w}^{\prime} \mathbf{x}$ & $\mathbf{r}^{\prime} \mathbf{b}$ & Adjusted Profit (AP) \\
\hline GMO & 587.80 & 185.88 & 36.05 & 365.86 \\
Non-GMO & 571.77 & 144.15 & 33.96 & 393.66 \\
\hline
\end{tabular}

Table 8. Differences in the adjusted profit for GMO and non-GMO systems if the quantity for GMOs is raised $10 \%$.

\begin{tabular}{cccccccc}
\hline \multirow{2}{*}{ System } & \multicolumn{2}{c}{ Stage 1 } & \multicolumn{2}{c}{ Stage 2 } & \multicolumn{2}{c}{ Stage 3 } & \multirow{2}{*}{$\begin{array}{c}\text { Adjusted Profit } \\
\text { Differences }\end{array}$} \\
\cline { 2 - 6 } & TFP & TPR & TFP & TPR & TFP & TPR & C. \\
\hline GMO & -778.97 & -92.65 & -0.05 & 0.00 & 54.32 & -39.28 & -856.62 \\
Non-GMO & 0.00 & 0.00 & 0.00 & 0.00 & 0.00 & 0.00 & 0.00 \\
\hline
\end{tabular}

Table 9. Adjusted profit for GMO and non-GMO rice systems if the quantity for Non-GMOs is raised $10 \%$.

\begin{tabular}{ccccc}
\hline System & $\mathbf{p}^{\prime} \mathbf{y}$ & $\mathbf{w}^{\prime} \mathbf{x}$ & $\mathbf{r}^{\prime} \mathbf{b}$ & Adjusted Profit (AP) \\
\hline GMO & 534.36 & 168.99 & 32.77 & 332.60 \\
Non-GMO & 628.94 & 158.57 & 37.35 & 433.02 \\
\hline
\end{tabular}

Table 10. Differences in the adjusted profit for GMO and non-GMO systems if the quantity for Non-GMOs is raised $10 \%$.

\begin{tabular}{|c|c|c|c|c|c|c|c|}
\hline \multirow{2}{*}{ System } & \multicolumn{2}{|c|}{ Stage 1} & \multicolumn{2}{|c|}{ Stage 2} & \multicolumn{2}{|c|}{ Stage 3} & \multirow{2}{*}{$\begin{array}{c}\text { Adjusted Profi } \\
\text { Differences }\end{array}$} \\
\hline & TFP & TPR & TFP & TPR & TFP & TPR & \\
\hline GMO & 813.34 & -92.69 & 0.05 & 0.00 & -48.11 & -39.28 & 633.30 \\
\hline Non-GMO & 0.00 & 0.00 & 0.00 & 0.00 & 0.00 & 0.00 & 0.00 \\
\hline
\end{tabular}


Table 2 shows data relating to the cultivation of the GMO and non-GMO products under study. The data contains the quantity and price for each output and input contained in the stages of the rice supply chain. The analyses of external factors used in this study were the Global Warming Potential (GWP) of greenhouse gases, Eutrophication Potential (EP) which describes the amount of phosphorus usage, Deforestation of natural areas (DEF), Environmental Toxicity (ET) which is the impact of pesticide use, Farmworker Toxicity (FT) which is the long-term impact for farm workers when applying pesticides to crops, Consumer Toxicity (CT) which is the potential impact on consumers and groundwater effects, and Loss of Employability (LE). The numerical examples of bad output quantities (b) and shadow prices (r) of externalities used are presented in Tables 3 and 4.

Table 5 shows that the highest adjusted profit was determined for the non-GMO observation equal to $\$ 393.66$ per ton of rice. This shows that non-GMO rice provides better performance than GMO rice. This observation was used as the benchmark observation for the computation of the TFP and TPR indicators. Adjusted profit, also called adjusted net income or adjusted earnings, represents the best estimate of what that true profit is. The calculation of the AP obtained from the sum between TPR and TPF that both in US \$.

Table 6 reveals that the positive values of AP show that the investigation is more sustainable than the benchmark observation, whereas negative values indicate that the investigation is less sustainable. From the research results it was found that there is a difference in the AP value of US $\$ 71.89$ per ton between GMOs and non-GMOs in stage 1, then there is a difference of US\$34.45 per ton for stage 3 . The overall value of the AP differences is US\$106.34. This means that GMO rice is no more sustainable compared to non-GMO rice. This is because the GMO crops could create environmental problems and also have a number of negative economic consequences [21]. According to Azadi and Ho [22], a major environmental concern with respect to GMO crops is the loss of biodiversity. Also, potentially, there are some environmental risks affecting ecosystems, agriculture, and health. Ironically, GMOs also have the potential to increase biodiversity [23]. Non-GMO as a holistic system that aims to produce food with minimal harm to ecosystems, animals, or humans, is the most prominent alternative farming system and is often proposed as a solution to less sustainable agriculture. Holistic systems planning has been central to the thinking of farmers for centuries, as they make decisions based on available land and production resources, balance land use for crops, livestock, and meeting needs of the family while producing additional food for sale or barter [24].

To identify the sensitivity of the model, the variation in value is calculated by increasing the quantity of GMOs and Non-GMOs by $10 \%$. The calculation results are presented in Tables 7-11.

Table 11. Resume of differences in the adjusted profit for GMO and non-GMO systems.

\begin{tabular}{cccc}
\hline Value of AP & Current & GMO $+\mathbf{1 0} \%$ & Non GMO +10\% \\
\hline GMO & 332.60 & 365.86 & 332.60 \\
Non-GMO & 393.66 & 393.66 & 433.02 \\
\hline Difference of AP & Current & GMO +10\% & Non GMO +10\% \\
\hline GMO & -106.34 & -856.62 & 633.30 \\
Non-GMO & 0.00 & 0.00 & 0.00 \\
\hline
\end{tabular}

Based on the above results, it can be seen that even with an increase of $10 \%$ in the quantity of the input and the output of GMO and Non-GMO products, the result is that non-GMO products always give a better performance. This can be identified from the non-GMO AP value, which is always higher than it is for GMOs. From the above calculation, it can also be seen that if the quantity of output and input of GMO products increased by $10 \%$, the difference generated in the AP value is US\$-856.62. This means that GMO products are not any more sustainable than non-GMO products. However, if the increase in quantity is made to Non-GMO rice, the difference generated in the AP value is equal to US \$633.30. This means GMO products are more sustainable compared to non-GMO products. This might be due to quantity differences (TFP component) include a lower use of biocides, i.e. pesticides, 
fungicides, and herbicides, in the non-GM chain. The main price difference (TPR component) is associated with the price premium paid per ton of non-GM rice, which reflects consumer preference for non-GM products. In doing sensitivity analysis we only see in terms of the number of quantity and price used. At what number the GMO is still safe in terms of sustainability. A summary of the results from the data processing is illustrated in Figure 2.

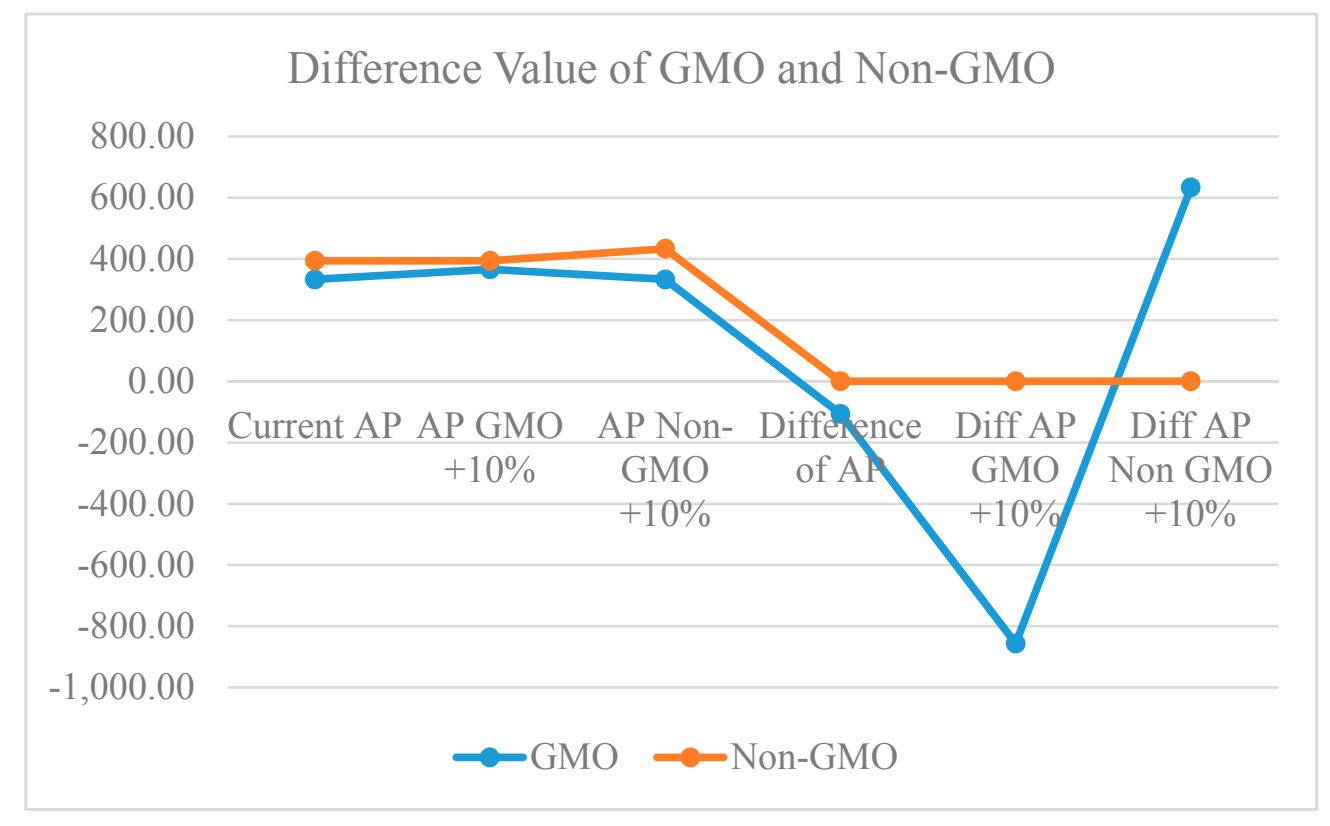

Figure 2. Difference value of GMO and Non-GMO.

Hence, the maintenance of the availability of sustainable rice can be accomplished by reducing the use of GMO seeds; the seed cost is also higher as a consequence of the expensive price. In addition, if too many GMO products are used, then the consumption of pesticides will also get higher as the majority of GMO products are vulnerable to pesticides. The high price of non-GMO rice also affects the sustainability of non-GMO products, as more products are produced and the high prices of products cause non-GMOs to become unsustainable.

\section{Conclusions}

The results suggest that the performance of non-GMO rice chains are better than the GMO chains. This can be seen from the results of the Adjusted Profit that consist of TFP and TPR. It can be perceived that from the differences in AP values, non-GMO rice is more sustainable than GMO products. The components that can be used as study materials related to economic, social, and environmental issues are the use of seeds, seed prices, the use of fertilizers and pesticides, and the use of fuel in the process of production and distribution of rice.

The DEA method was used to propose a performance measurement model of sustainable agri-food supply chains for GMOs and Non-GMOs. Numerical analysis showed that the model could be used to determine Adjusted Profit (AP) with Total Price Recovery (TPR) indicators and Total Factor Productivity (TFP). The research results found that performances of non-GMO rice chains are better than GMO rice, which means non-GMO rice is more sustainable.

Therefore, in order to maintain the sustainability of GMO and non-GMO products, consideration should be given to the use of such components in the supply chain process of GMO and non-GMO products. In the future, it is expected that this research will continue to inform the policies regarding GMO product usage compared to non-GMO products in Indonesia, in order to maintain food sustainability in Indonesia. 
Author Contributions: Conceptualization and supervision, W.S.; methodology, software, draft preparation, V.H.L.S.; validation, A.M.; review and editing, M.H.

Funding: The research is supported by Institute for Research and Community Service, Universitas Sebelas Maret with Hibah Penelitian Unggulan UNS (PU-UNS) Research Program (Contract No. 543/UN27.21/PP/2018) and this project is partly supported by the Ministry of Education Malaysia with vot number R.J130000.7824.4F957.

Acknowledgments: The authors gratefully acknowledge the support of the Institute for Research and Community Service, Universitas Sebelas Maret and the Ministry of Education Malaysia.

Conflicts of Interest: The authors declare no conflict of interest. The funders had no role in the design of the study, in the collection, analyses, or interpretation of data, in the writing of the manuscript, or in the decision to publish the results.

\section{References}

1. Lambert, D.M.; Cooper, M.C.; Pagh, J.D. Supply Chain Management: Implementation Issues and Research Opportunities. Int. J. Logist. Manag. 1998, 9, 1-20. [CrossRef]

2. Iakovou, E.; Vlachos, D.; Achillas, C.; Anastasiadis, F. A Methodological Framework for the Design of Green Supply Chains for the Agrifood Sector. In Proceedings of the 2nd International Conference on Supply Chains (2nd Olympus ICSC), Katerini, Greece, 5-6 October 2012; Available online: www.teicm.gr/logistics/images / logisticsdocs /...5/5_1_ICSC_12_IAKOVOU.pdf (accessed on 5 November 2017).

3. Yakovleva, N.; Sarkis, J.; Sloan, T. Sustainable Benchmarking of Supply Chains: The Case of the Food Industry. Int. J. Prod. Res. 2011, 50, 1297-1317. [CrossRef]

4. UN. World Population Prospects, the 2012 Revision; United Nation: New York, NY, USA, 2013.

5. FAO. World Agriculture: Towards 2015/2030; Earthscan Publication: London, UK, 2003.

6. Martin, M.A.; Baumgardt, B.R. The Origin of Biotechnology ans Its Potential for Agriculture. In Agricultural Biotechnology: Issues and Choices; Purdue Research Foundation: West Lafayette, IN, USA, 1991.

7. Juma, C. The New Harvest: Agricultural Innovation in Africa; Oxford University Press: Oxford, UK, 2015.

8. James, C. Preview: Global Status of Commercially Transgenic Crops: 2003; (ISAAA Briefs No. 30-2003); The International Service for the Acquisition of Agri-biotech Applications: Ithaca, NY, USA, 2003.

9. Karmana, I.W. Adopsi Tanaman Transgenik dan Beberapa Aspek Perkembangannya. Ganec Swara 2009, 3 , 12-21.

10. Santosa, D.A. Analisis Resiko Lingkungan Tanaman Transgenik. J. Ilmu Tanah Dan Lingkung. 2000, 3, 32-36.

11. USDA Foreign Agricultural Service. Agricultural Biotechnology Annual; Global Agricultural Information Network: Bangkok, Thailand, 2015.

12. Sun, Y.; Yu, X.; Tan, Z.; Xu, X.; Yan, Q. Efficiency Evaluation of Operation Analysis Systems Based on Dynamic Data Envelope Analysis Models from a Big Data Perspective. Appl. Sci. 2017, 7, 624. [CrossRef]

13. Fu, H.; Qu, Y.; Pan, Y. Efficiency of Cassava Production in China: Empirical Analysis of Field Surveys from Six Provinces. Appl. Sci. 2018, 8, 1356. [CrossRef]

14. Ma, F.; Wang, W.; Sun, Q.; Liu, F.; Li, X. Integrated Transport Efficiency and Its Spatial Convergence in China's Provinces: A Super-SBM DEA Model Considering Undesirable Outputs. Appl. Sci. 2018, 8, 1698. [CrossRef]

15. Gaitan-Cremaschi, D.; Kamali, F.P.; van Evert, F.K.; Meuwissen, M.P.M.; Oude Lansink, A.G.J.M. Benchmarking the sustainability performance of the Brazilian non-GM and GM soybean meal chains: An indicator-based approach. Food Policy 2015, 55, 22-32. [CrossRef]

16. Gaitan-Cremaschi, D.; Meuwissen, M.P.M.; Oude Lasink, A.G.J.M.; Jansen, D.M.; Van Evert, F.K.; Bosch, R.; Van de Pol, M.A. Novel Index Approach for Measuring Biomass Sustainability. In Issue Paper for the Organization for Economic Co-Operation and Development (OECD) Workshop on "Sustainable Biomass Drives the Next Bio-Economy"; OECD: Paris, France, 2014.

17. Barnes, A.P. Publicly-funded UK agricultural R\&D and social total factor productivity. Agric. Econ. 2002, 27, 65-74.

18. Barnes, A.P.; Mcvittie, A. Measuring the Sustainability of the UK Food Chain; Working Papers 46003; Scotland's Rural College, Land Economy \& Environment Research Group: Scotland, UK, 2006.

19. Glending, M.J.; Dailey, A.G.; Williams, A.G.; Van Evert, F.K.; Goulding, K.W.T.; Whitmore, A.P. Is it possible to increase the sustainability of arable and ruminant agriculture by reducing input? Agric. Syst. 2009, 99, 117-125. [CrossRef] 
20. Central Bureau of Statistics. Available online: https://www.bps.go.id/ (accessed on 1 November 2017).

21. Viswanathan, P.K.; Lalitha, N. GM technology and sustainable agriculture future: Empirical evidences from Bt cotton farmers in Maharashtra and Gujarat in India. J. Dev. Agric. Econ 2010, 2, 7-17.

22. Azadi, H.; Ho, P. Genetically modified and organic crops in developing countries: A review of options for food security. Biotechnol. Adv. 2010, 28, 160-168. [CrossRef] [PubMed]

23. Carpenter, J.E. Impact of GM crops on biodiversity. Gm Crop. 2011, 1, 7-23. [CrossRef]

24. Francis, C.A.; Wezel, A. Agroecology and Agricultural Change. Int. Encycl. Soc. Behav. Sci. 2015, 1, $484-487$. 